\title{
Analysis of Students' Attitude Home Economics Group Study Programs in the Field of Science and Its Influence on Science Learning Results
}

\section{Dwi Atmanto, Sri lrtawidjajanti, and Aniesa Puspa Arum}

Study Program of Vocational Education Cosmetology, Faculty of Engineering, State University of Jakarta, DKI Jakarta, Indonesia

\section{Abstract}

The study program in the Home Economics (IKK) FT UNJ including the IPS group gave science courses such as chemistry and physics. The purpose of this study was to determine the attitudes of students in the IKK study program in the fields of study and whether there was an influence on the results of learning science. There were 214 IKK students who were sampled, namely 53 people of culinary study program, 54

Corresponding Author: Dwi Atmanto

dwi_atmanto@yahoo.com

Received: 11 January 2019

Accepted: 14 February 2019

Published: 25 March 2019

Publishing services provided by Knowledge E

(c) Dwi Atmanto et al. This article is distributed under the terms of the Creative Commons

Attribution License, which permits unrestricted use and redistribution provided that the original author and source are credited.

Selection and Peer-review under the responsibility of the 3rd ICTVET 2018 Conference Committee. people of fashion, 53 of PKK, and 54 for makeup. This research method is based on correlational surveys. Characteristics of data was collected by TOSRA (Test of Science Related Attitudes), which is divided into seven aspects, namely social implications of science, scientific norms, public attitudes, application of attitudes, preferences, and interests in time interests in science, and a career interest in science. Data on student behavior when analyzed qualitatively, the results show that social practices are sufficient, self-concept is sufficient, attitudes are lacking, application of adequate attitudes, preferences. Enough learning, interest in free time at work, and interest in careers in the field of science disagree. In addition, there are several factors that can be used to study things: $p>0.05$ with an increase in attitudes toward learning outcomes is the remaining $41 \%$ are repatriated by other factors such as school origin, level of intelligence, social environment and other factors.

Keywords: science attitude, IKK study program, learning outcomes of science, TOSRA attitude test

\section{Introduction}

Educational challenges in the 21 st century are not only related to negative student behavior, but are related to the behavior of teachers who do not give examples and are exemplary as educators. To respond to the above problems, the need for the cultivation of values so that the values taught by the teacher and other educators can shape the character of students, education, not only teaches the child in the cognitive domain, 
but is able to form the domain of affective and psychomotor aspects [1,9]. Teachers not only teach in the classroom but must be able to educate and guide students toward positive and environmentally friendly behavior [2].

At the Jakarta State University there is a Faculty of Engineering which is an implementing element of some of the main tasks of the university in education and teaching, research, community service in the field of vocational technology and engineering [8]. Prospective students who enroll in this IKK clump study program can come from the high school level of science and social studies majors as well as those from vocational schools, because the IKK clump study program is included in the vocational college class. Based on the data of the IKK clump students who came from the SMA/MA (Senior High School) level there were 403 students. Then students from the vocational level are as many as 60 students. Which means that only $13 \%$ of students who come from the vocational level from the total number of students are IKK clumps. During studying at UNJ, in the curriculum there are courses that are included in the field of science include Basic Physics, Basic Chemistry, Anatomy of Physiology and several other subjects related to science as well as related to the vocational study program.

Some of the courses mentioned above are part of science, so that students 'attitudes toward the subject are included in the students' attitude toward science. The attitude of students in the IKK group to the subject of science can be said to be less good. This is in line with the results of the initial interview with one of the students, where the student said that he had difficulty understanding the material so that the learning outcomes tended to be low. In addition, students also did not think that in the IKK family study program there were science courses because most students came from high schools and Non-Mathematics Vocational Schools.

Seeing the importance of the attitude of IKK students toward science courses (IPA) such as Basic Chemistry and Basic Physics and the low attitudes of 2015 IKK education students toward science subjects, the researchers want to do a research to determine the attitude of IKK students to the field of science. The attitude dimension used refers to the scientific attitude dimension found in TOSRA are social perceptions of science, self-concept in science, pleasure in science lessons and interest in a career in science.

\section{Methods and Equipment}

This study uses a mixed research approach. This type of research in this combination research uses concurrent embedded strategy model. The focus of the research is through quantitative descriptive qualitative methods with the study of documents and 
libraries that are in accordance with the material to be studied. Document data derived from books, articles, research reports (as secondary data), internet and materials that are in line with the research objectives. The data obtained is then analyzed through descriptive methods in accordance with the writer's understanding in conducting this study.

This research was conducted in the IKK group study program, namely Culinary Education, Fashion Design education and Cosmetology education, Jakarta State University. The research time is the odd semester of the 2018/2019 school year or July to September 2018. The methods for collecting data are through literature review in accordance with the object to be studied and analyzed. So that this study is in accordance with what is expected, the authors limit the scope of research, namely the impact of science learning on the character of the student environment which includes curiosity about the environment, cooperation, responsibility, and discipline.

The target of the 2015 IKJ FT UNJ environment study program with the number of respondents 214 people. The procedure for collecting data in this study is (1) distribution of attitude and documentation questionnaires, (2) analysis of the results of attitude questionnaires, (3) interviews and documentation, (4) transcripts of data interviews, (5) documentation studies. Data analysis techniques through the Miles and Huberman models [10] uses descriptive statistics and data validity tests, in the following order:

(1) Reducing data by summarizing, choosing key things, focus on important things; (2) Presentation of data in category table and diagram and tables for the presentation of questionnaires; (3) Conclusion (verification) is drawing conclusions to find out the attitudes of the IKK students' attitudes toward science subjects. In this study, the credibility test was carried out by triangulation of data collection techniques, namely interviews, giving questionnaires to students and documenting the conditions of the research location.

\section{Results}

In the table below shows the attitude of students in the field of science in the mastery of cognitive aspects is $55.4 \%$, affective aspects of mastery is $52.4 \%$ and conasi mastery is $32.4 \%$.

After studying the fields of Basic Chemistry and Basic Physics, students have a high level of knowledge and attitude toward science, but students are less likely to agree to the application or career in science. 
TABLE 1: Cognitive Percentage of Respondents in the Attitudes of Science.

\begin{tabular}{|c|c|c|c|c|c|c|c|c|c|}
\hline & & Cognitive & & & Affective & & & Conation & \\
\hline Category & $\begin{array}{l}\text { Positive } \\
\text { score } \\
\text { (SS + S) }\end{array}$ & $\begin{array}{l}\text { Neutral } \\
\text { score }\end{array}$ & $\begin{array}{c}\text { Negative } \\
\text { score } \\
\text { TS+TS) }\end{array}$ & $\begin{array}{l}\text { Positive } \\
\text { score } \\
\text { (SS + S) }\end{array}$ & $\begin{array}{l}\text { Neutral } \\
\text { score }\end{array}$ & $\begin{array}{l}\text { Negative } \\
\text { score } \\
\text { (TS+STS) }\end{array}$ & $\begin{array}{c}\text { Positive } \\
\text { score } \\
\text { (SS + S) }\end{array}$ & $\begin{array}{l}\text { Neutral } \\
\text { score }\end{array}$ & $\begin{array}{c}\text { Negative } \\
\text { score } \\
\text { (TS + } \\
\text { STS) }\end{array}$ \\
\hline Positive & 155.67 & 45.00 & 13.33 & 111.07 & 81.33 & 21.60 & 57.11 & 97.78 & 59.11 \\
\hline Negative & 81.60 & 82.20 & 50.20 & 113.07 & 58.53 & 42.40 & 77.10 & 80.50 & 56.40 \\
\hline Total & 237.27 & 127.20 & 63.53 & 224.13 & 139.87 & 64.00 & 134.21 & 178.28 & 115.51 \\
\hline Average & 118.63 & 63.60 & 31.77 & 112.07 & 69.93 & 32.00 & 67.11 & 89.14 & 57.76 \\
\hline Percentage & $55.4 \%$ & $29.7 \%$ & $14.8 \%$ & $52.4 \%$ & $32.7 \%$ & $15.0 \%$ & $31.4 \%$ & $41.7 \%$ & $27.0 \%$ \\
\hline
\end{tabular}

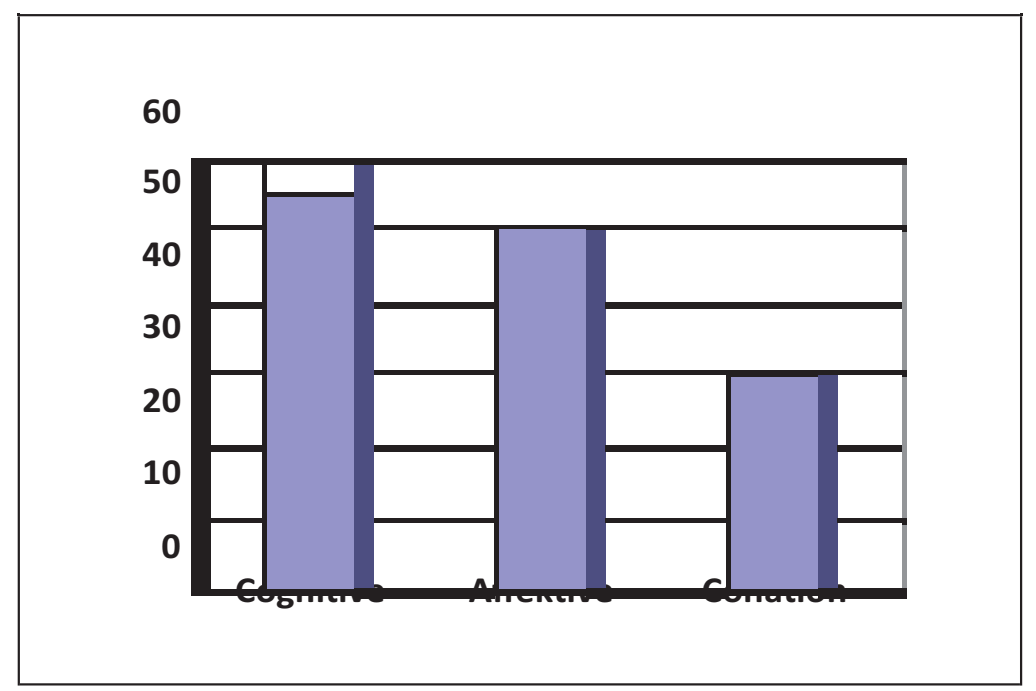

Figure 1: Percentage of Respondents' Attitudes in Science.

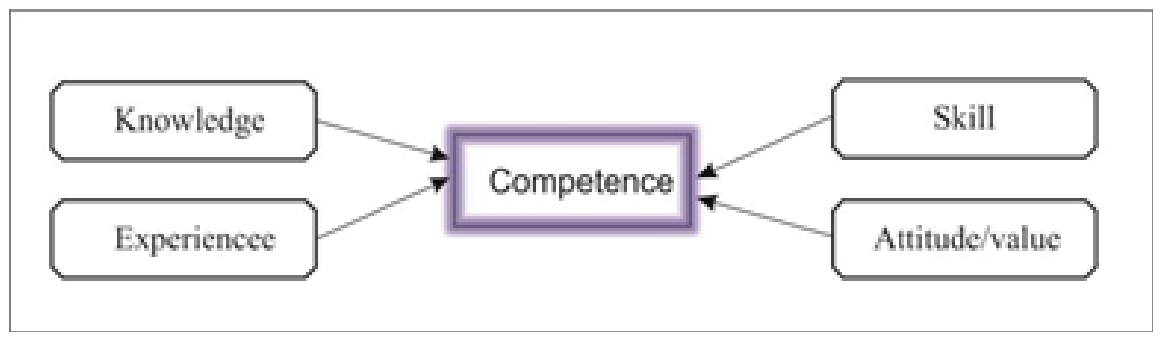

Figure 2: Student Competency consists of a variety of components and is very personal and intact. To form competent competencies, one must have knowledge, experience, skills and attitudes/values [5].

Competence is personal and complex and is a whole that describes the potential that includes knowledge, skills, attitudes and values that are owned by someone who is related to the teaching profession. This is in accordance with the statement of the concept of teacher competence of Ministry of National Education. Students must be able to use these aspects of competence in their daily life and work, and if the impact of their actions or performance can be accepted and in accordance with the values of the community in their environment. 
TABLE 2: Percentage of Respondents' Attitudes to Science.

\begin{tabular}{|l|c|c|c|}
\hline Category & $\begin{array}{c}\text { Positive score } \\
\text { (SS+S) }\end{array}$ & Neutral score & $\begin{array}{c}\text { Negative score } \\
\text { (STS+TS) }\end{array}$ \\
\hline Positive & 105.17 & 77.09 & 31.74 \\
\hline Negative & 93.80 & 71.57 & 48.63 \\
\hline Total & 198.97 & 148.66 & 80.37 \\
\hline Average & 99.49 & 74.33 & 40.19 \\
\hline Percentage & $46.5 \%$ & $34.7 \%$ & $18.8 \%$ \\
\hline
\end{tabular}

The table above shows the attitude of IKK students to be quite enthusiastic about taking advantage after the science lecture that is positive attitude $46.5 \%$, and the attitude of not agreeing to the field of science is only $18.8 \%$.

TABLE 3: Percentage of Attitudes to Science Aspects.

\begin{tabular}{|c|c|c|c|c|c|c|c|}
\hline Category & $\begin{array}{c}\text { Positive } \\
\text { Score (SS } \\
+ \text { S) impact } \\
\text { of social } \\
\text { science }\end{array}$ & $\begin{array}{l}\text { Positive } \\
\text { score (SS + } \\
\text { S) scientist } \\
\text { perception }\end{array}$ & $\begin{array}{l}\text { Positive } \\
\text { score (SS + } \\
\text { S) science } \\
\text { research }\end{array}$ & $\begin{array}{c}\text { Positive } \\
\text { score (SS + } \\
\text { S) science } \\
\text { application }\end{array}$ & $\begin{array}{l}\text { Positive } \\
\text { score } \\
\text { (SS+S) like } \\
\text { in science }\end{array}$ & $\begin{array}{l}\text { Positive } \\
\text { score (SS + } \\
\text { S) interest } \\
\text { of day off } \\
\text { in science }\end{array}$ & $\begin{array}{l}\text { Positive } \\
\text { score (SS + } \\
\text { S) science } \\
\text { works }\end{array}$ \\
\hline Positive & 151.00 & 144.80 & 113.20 & 117.60 & 102.40 & 50.00 & 57.20 \\
\hline Negative & 79.20 & 84.00 & 83.40 & 140.80 & 115.00 & 91.20 & 63.00 \\
\hline Total & 230.20 & 228.80 & 196.60 & 258.40 & 217.40 & 141.20 & 120.20 \\
\hline Average & 115.10 & 114.40 & 98.30 & 129.20 & 108.70 & 70.60 & 60.10 \\
\hline Percentage & $53.8 \%$ & $53.5 \%$ & $45.9 \%$ & $60.4 \%$ & $50.8 \%$ & $33.0 \%$ & $28.1 \%$ \\
\hline
\end{tabular}

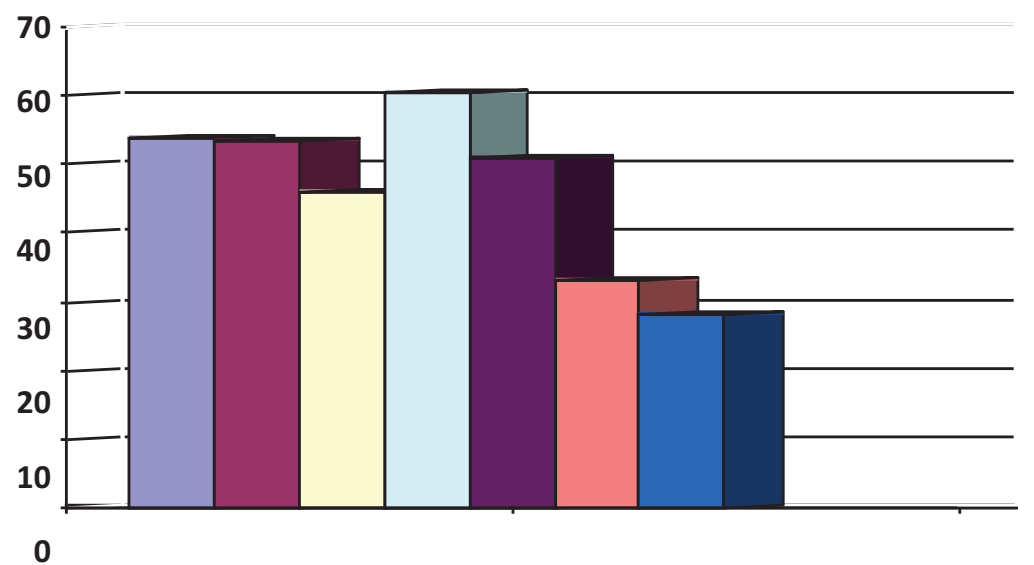

Figure 3: Percentage of Aspects of Attitude to Science (social impacts, self-concept, scientific research, application of science, science's favorite, scientific interest, and science profession).

When referring to the results of research on students' scientific attitudes at each meeting in lectures on science subjects such as basic chemistry and basic physics as follows [2]: 1). Social taste. The average percentage of students' scientific attitude in the IKK group for curiosity indicators was $53.8 \%$ was developed by using 3 descriptors, which are looking for information in accordance with the topic, asking for something 
that has not been understood, recording important things; 2). The attitude of science scientists. The average percentage of students' scientific attitudes for discipline indicators was $53.5 \%$ assessed using 3 descriptors, namely completing activities on time, not leaving the group during lectures and not playing games; 3). Science research attitudes. The average percentage of students' scientific attitudes to responsibility indicators is 45.9\% (Good category) assessed by using 3 descriptors which are trying to complete all the tasks assigned, trying to find answers and be able to express opinions.

Several aspects of scientific attitudes can be developed and instilled in students, one of them is with a responsible attitude [11]; 4). Attitude of the application of science. The average percentage of students' scientific attitudes for meticulous indicators is $60.4 \%$ (good). This indicator is assessed by using 3 descriptors, which are serious in working, doing tasks with procedures and doing the tasks carefully; 5). Attitude and interest in science. The average percentage of students' scientific attitudes for pleasure indicators is $50.8 \%$ and science interest is $33 \%$. This indicator is assessed using 3 descriptors which can work together in groups, share information, participate in tasks; 6). Activities working in the field of science related to how students work together in completing their tasks and sharing information (28.1\%). Cooperation can eliminate mental obstacles due to limited experience and narrow perspective [7].

The results of studying science such as lectures in Basic Chemistry and Basic Physics are:

TABLE 4: Description of Chemistry and Physics Courses.

\begin{tabular}{l|c|c|c|c|}
\hline & \multicolumn{4}{|c}{ Courses } \\
\hline Score & \multicolumn{2}{|c|}{ Chemistry } & \multicolumn{2}{c|}{ Physics } \\
\hline & F & $\%$ & F & $\%$ \\
\hline A & 16 & 7.5 & 8 & 3.7 \\
\hline A- & 15 & 7 & 9 & 4.2 \\
\hline B+ & 8 & 3.7 & 24 & 11.2 \\
\hline B & 31 & 14.6 & 56 & 26.2 \\
\hline B- & 113 & 52.8 & 95 & 44.3 \\
\hline C+ & 30 & 14 & 13 & 6.2 \\
\hline C & 1 & 0.4 & 3 & 1.4 \\
\hline C- & 0 & 0 & 6 & 2.8 \\
\hline Total & $\mathbf{2 1 4}$ & 100 & $\mathbf{2 1 4}$ & 100 \\
\hline
\end{tabular}

The findings show that the actual attitude of students toward the field of science is categorized as high enough (above 50\%) but students do not have enough achievement skills in science courses such as Basic Chemistry and Basic Physics. This is likely because students have difficulty receiving Chemistry and Physics science course 
TABLE 5: Basic Chemistry on Attitudes of Crosstabulation Students.

\begin{tabular}{|l|c|c|c|c|}
\hline \multicolumn{1}{|c|}{} & \multicolumn{3}{|c|}{ Student attitude } & \\
\hline Chemistry & & High & enough & Total \\
\hline & A & 3 & 12 & 15 \\
\hline & B & 38 & 130 & 168 \\
\hline Total & C & 5 & 26 & 31 \\
\hline
\end{tabular}

\begin{tabular}{l|c|c|c|}
\multicolumn{3}{c}{ Chi-Square Tests } \\
& \multicolumn{1}{c}{ Asymp. Sig. } \\
\hline & Value & df & (2-sided) \\
\hline Pearson Chi-Square & $0.675^{a}$ & 2 & 0.714 \\
\hline Likelihood Ratio & 0.711 & 2 & 0.701 \\
\hline Linear-by-Linear & 0.273 & 1 & 0.502 \\
\hline Association & & & \\
\hline$N$ of Valid Cases & 214 & & \\
\hline
\end{tabular}

Note: ${ }^{a} 1$ cells $(16.7 \%)$ have expected count less than 5 ; the minimum expected count is 3.22 .

TABle 6: Basic Physics on Attitudes of Crosstabulation Students.
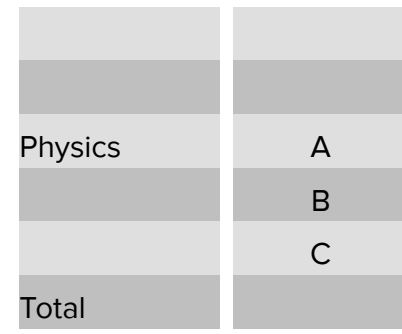

\begin{tabular}{|c|}
\hline Student \\
\hline High \\
\hline 2 \\
\hline 37 \\
\hline 7 \\
\hline 46 \\
\hline
\end{tabular}

\begin{tabular}{c} 
enough \\
\hline 5 \\
146 \\
17 \\
168 \\
\hline
\end{tabular}

\begin{tabular}{|c|}
\hline Total \\
\hline 7 \\
\hline 183 \\
\hline 24 \\
\hline 214 \\
\hline
\end{tabular}

\begin{tabular}{|c|c|c|c|}
\hline \multicolumn{4}{|c|}{ Chi-Square Tests } \\
\hline & & & Asymp. Sig. \\
\hline & Value & $\mathrm{df}$ & (2-sided) \\
\hline Pearson Chi-Square & $1.221^{a}$ & 2 & 0.543 \\
\hline Likelihood Ratio & 1.15 & 2 & 0.563 \\
\hline $\begin{array}{l}\text { Linear-by-Linear } \\
\text { Association }\end{array}$ & 0.36 & 1 & 0.548 \\
\hline$N$ of Valid Cases & 214 & & \\
\hline
\end{tabular}

material with the background of most students from Vocational High Schools and NonMathematics High Schools. These results indicate that the majority of IKK FT UNJ students are groups of students who are good (positive) facing science but still having difficulty in attending science courses. 


\section{Discussion}

The essence of science includes four main elements [13]:(1) the attitude of curiosity about natural objects or phenomena, living things, and cause and effect relationships that create new problems that can be solved through the correct procedure, (2) processes, procedures problem solving through scientific methods, scientific methods include the preparation of hypotheses, the design of experiments or experiments, evaluation, measurement, and analysis of conclusions.

(3) products, in the form of facts, principles, concepts, theories and laws, (4) Applications, the application of scientific methods and concepts in everyday life. The four elements above are intact scientific characteristics and cannot be separated from each other.

Each subject requires competency that contains good values and life such as: honesty, tenacity, cooperation, competition, nationality, courtesy, unity, sportsmanship and so on [6]. Learning science can be used as an approach to building moral, character, and noble character. Learning conducted in groups will enable students to share their feelings, ideas, knowledge, experiences, responsibilities and help each other, so that students can learn to collaborate socially, communicate and socialize [12]. Fraser said [4] There are 4 dimensions of student attitudes toward science lectures developed from TOSRA that is 1) perception of science lecturer, 2) self-concept, 3) pleasure to science lesson, 4) career engagement in science.

The results of this study indicate the average of students' perceptions of the field of science including how the lecturer teaches science is $80 \%$ states good. Lecturers are able to establish scientific communication to students so that students feel happy to receive science lessons.

From the theory above developed 4 dimensions of students' attitudes to science learning, namely perceptions about learning science, self-concept in the field of science, a fondness in learning science, and interest in working in science [4].

Through science learning such as lectures in basic chemistry and basic physics, prospective teacher students will get the values that emerge during the science course. As in chemistry learning, students will know the process of reactions that occur in nature. The role of science learning in character building can be developed through activeparticipatory, creative-innovative learning models with the learning process not only in the classroom but also in the (natural) environment. Through scientific observations that occur in nature, it is hoped that changes in the behavior of environmental characteristics will be better. 


\section{Conclusions}

Based on the research that has been done, students' attitudes toward science subjects such as Basic Chemistry and Basic Physics in the Jakarta Vocational Education Program for Dressing, Dressing and Cosmetology of the State University of Jakarta include three attitudinal dimensions namely cognitive, affective and connective. These three dimensions of attitudes toward science are quite good on average above $50 \%$, but the dimensions of the connotation of science are below $50 \%$ or categorized as not good.

Students 'attitudes toward science with the TOSRA dimension category show social attitudes, scientists' self-attitudes, enjoyment, and the average application of life science is well above $50 \%$, but the research dimension of science, interest in the scientific profession is in the low category, that is under $50 \%$.

Actually the attitude of students toward the field of science is categorized as quite high (above 50\%) but students do not have enough ability to excel in science lectures such as Basic Chemistry and Basic Physics. This is likely because students have difficulty receiving Chemistry and Physics science course material with the background of most students from Vocational High Schools and Non-Mathematics High Schools. Learning science can contribute to the formation of students' environmental characteristics, including knowing the importance of cooperation, honesty, perseverance, commitment, hard work, time management, and discipline.

\section{Funding}

This research was funded by BLU funds from the Faculty of Engineering, Jakarta State University.

\section{Acknowledgment}

The researcher expressed his gratitude and appreciation to the students involved in the research and fellow lecturers who had provided input for the perfection of the research results.

\section{References}

[1] Aslan. 2017. Pumping Teacher dalam Tantangan Pendidikan Abad 21. Muallimuna Jurnal Madrasah Ibtidaiyah. Vol. 2 No. 2 April 2017. https://media.neliti.com/media/ 
publications/222462.

[2] Atmanto, Dwi. 2018. Science Approach to Home Economics Student for Improving Intellectual social Environment. Proceeding International Conference on University and Intellectual Culture (ICUIC). FIS UNJ, 27-28 July 2018.

[3] B. Uno, Hamzah. 2008. Profesi Kependidikan Problema. Solusi, dan Reformasi di Indonesia. Jakarta: Bumi Aksara.

[4] Fraser, B. J. (1981). Test of Science-Related Attitudes Handbook. [Online]. Tersedia di: https://www.pearweb.org/atis/tools/13 [Diakses 17 Maret 2018]

[5] Hidayat, Iceng. 2007. Peranan Keyakinan Guru terhadap Hakikat dan Belajar Mengajar Sains dalam Pengembangan Profesionalisme. Cakrawala Pendidikan, Februari 2007, Th.XXVINo.1. http://download.portalgaruda.org/article.php?article.

[6] Jalal, F. 2001. Akhlak dan Pembanguan Pendidikan Karakter. Milad JSIT. Februari 2001.

[7] Jhonson, Elaine B.(2007). Contextual Teaching and Learning. MLC. Bandung.

[8] Kementerian Pendidikan Dan Kebudayaan. (2013). Buku Pedoman Akademik Fakultas Teknik 2013/2014. Jakarta: Fakultas Teknik, Universitas Negeri Jakarta.

[9] Lickona, Thomas. (2012). Character Matters. Jakarta: PT. Bumi Aksara.

[10] Nurjanah, Tity., et al. (2017) Sikap Mahasiswa terhadap Mata Kuliah Fisika Dasar pada Program Studi Pendidikan Fisika Fakultas Keguruan dan IImu Pendidikan Universitas Jambi.

[11] Sardinah,dkk. (2012) Relevansi Sikap Ilmiah Siswa Dengan Konsep Hakikat Sains Dalam Pelaksanaan Percobaan Pada Pembelajaran IPA di SDN Kota Banda Aceh. Jurnal Pendidikan Serambi IImu. Volume 13 Nomor 2 Tahun 2012. Hal 70-80.

[12] Suherman, Adang. (2002). Penelitian Korelasional dan Komparasi dalam Kurikulum dan Pengajaran. Makalah. Bandung. Pasca Sarjana UPI.

[13] Zubaidah, Siti. 2011. Pembelajaran Sains (IPA) sebagai Wahana Pendidikan Karakter. Makalah pada Seminar Nasional II. Pekanbaru.https://www.researchgate. net/publication. Diakses tanggal 5 Agustus 2018.

[14] Zuchdi, D., Prasetya. Z.K. dan Masruri, M.S. 2010. Pengembangan Model Pendidikan Karakter Terintegrasi dalam Pembelajaran Bidang Studi di Sekolah Dasar. Cakrawala Pendidikan, Mei 2010. Th. XXIX, Edisi Khusus Dies Natalis UNY. 